\title{
十二指腸蟲病及ビ其他一二疾患患者J 植物性神經系統機能檢查成績二就テ
}

阔山醫科大學柿沼內科数宝

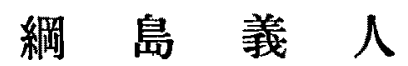

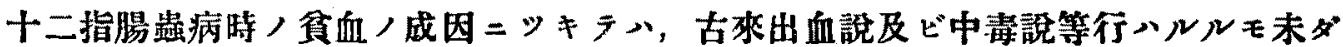

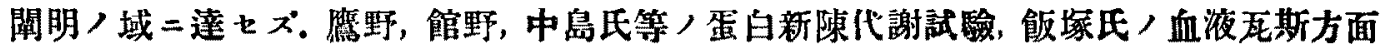
ヨリノ研究及ビ林氏，生物化學的研究等ノ結果ニョレバ，中毒說二有力ノ根㨜 ラレタルガ如シ，又我教室ノ岡氏ノ「ウロビリン」尿，蓮池氏ノ網狀赫血球ヨリノ成績 等ヨリ考フルモ，該病時常二高度ナル溶血現象ガ體內ニラ起ルモノトモ信ゼラレズ。 又吾々ノ常二烸彇的二經驗スル如ク，十二指腸蟲ノ寄生ノ程度ト貧血度トハ必ズシモ

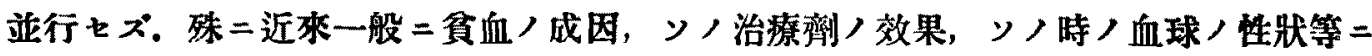
關シ，特二內分汹線ノ機能卜ノ關係ニツキラハ，論議七ラルルモ未が分明セズ. 余心

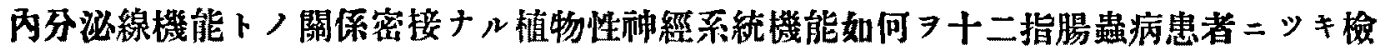

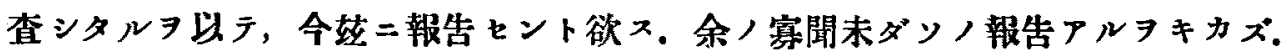
植物性神經系統機能檢査方法トシラ，余ハ從桃用ヒラレタル「ドレナリン」「アト

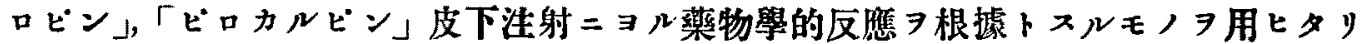
盖シコノ方法ハェっピンダル及ビへス雨氏以爽器械的方法ト共二, 諸家ニヨリ用ヒラレ タルモノナレドモ，コレ等藥物ハ，當該神經系統末梢二作用スルモノニテ，從ッテコ

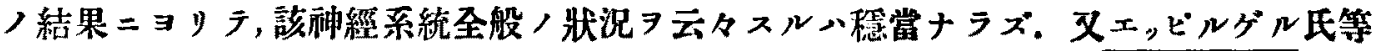

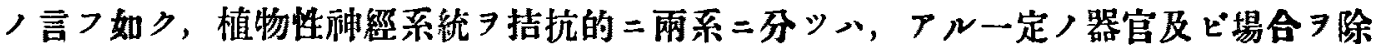
キテハ如何ト信ズルモ，今日尚ホ優レタル檢査方法栄出サレザルタメ，且ハ䳡法二ヨ

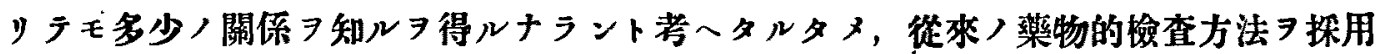
セリ、又藥物ノ泩入方法ニッキラモ從來、皮下，最近八静脉內泩射が一二學者ニヨリ 推獎七ラレ居リ，余モ靜㕄內注射 7 行ヒタルコトアルモ, 一二不快ノ副作用二遭遇シ タルコトフルョ以テ，本包入皮下洼射方法ニヨル結果ノミヨ迅ブ. 又藥物ノ用量及ビ 
結果ノ物断ニッキラモ, 諸家各獨持ノ見地ヨリ程々ニセラレ居ルモ, 余小大體上田氏

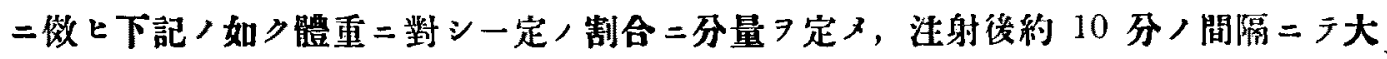
凡 2 時間後迄

・ケアドレナリン」試驗 ニテハ

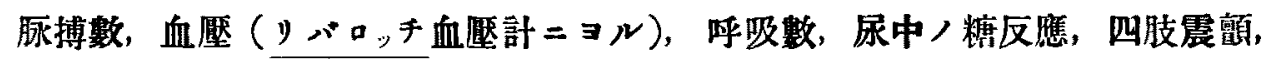
心悸光進，皮䖉/蒼白及ビ政畵症，腱反射等ニシキ。

「アトロビン」試驗ニテふ

脉搏數，口渴，心悸立進，呼吸數，腱反射.

「ピロカルピン」試驗 =テハ

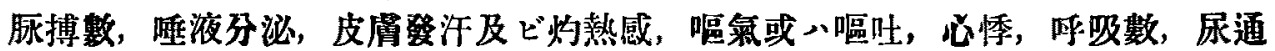
窘迫, 腱反射

等ノ狀態 ニツキ詳細ニ觀察シ，其結果中

「アドレナリン」試驗ニテハ

主要症候トシテ

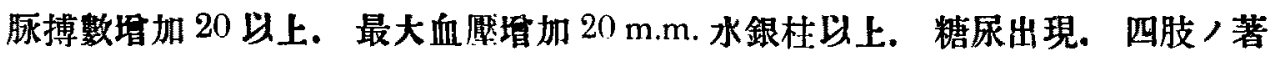
明ナル震顫.

副症候トシテ

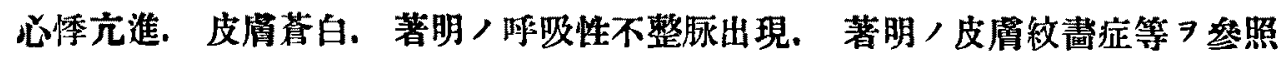
i

「アトロピン」試驗ニテメ

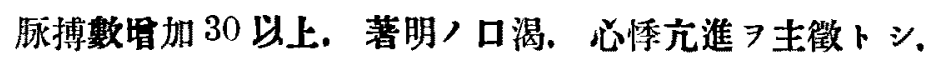

「ピロカルピン」試驗ニテふ

哽液分泌量 75 乃至 $200 \mathrm{cc}$ 以上. 皮䖉汗顆生成。嘔氣或、嘔姓アルモノヨ主徵 トシ.

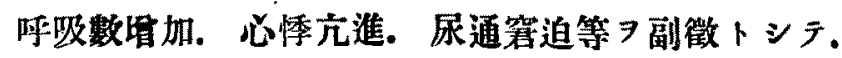

各反㮣度ノ强，中，弱ノ程度

ソノ检查成綪 ヨ列記スレバ次ノ如シ。 
第 一 例

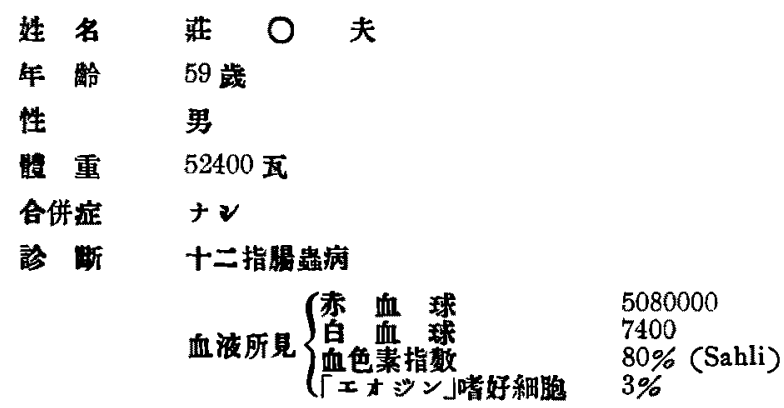

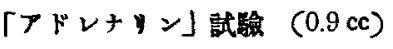

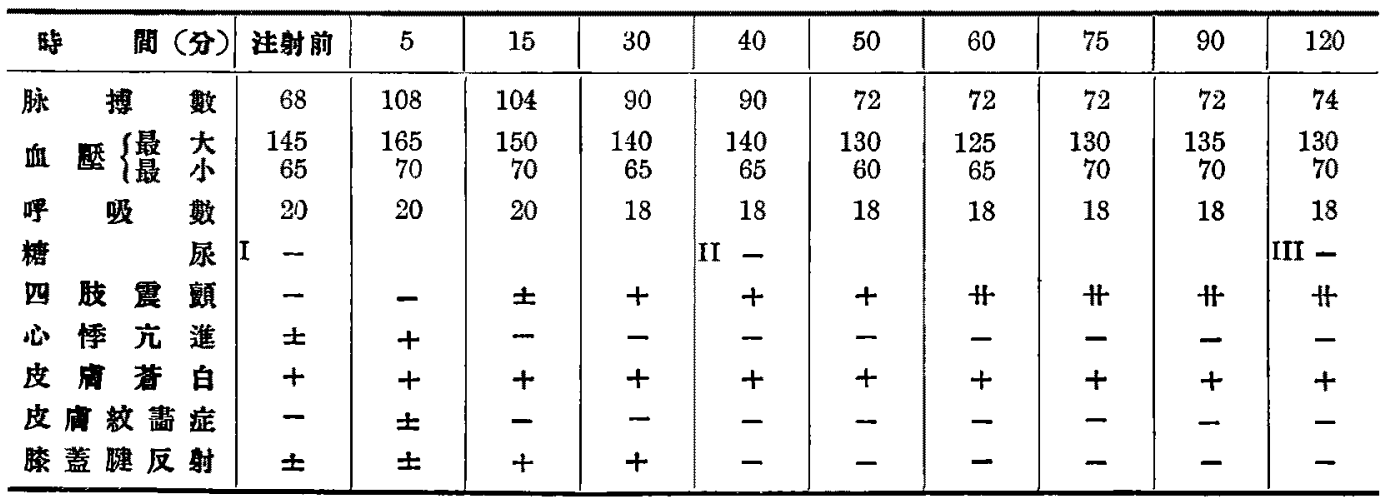

「アトロピン」訊驗 (0.9cc)

\begin{tabular}{|c|c|c|c|c|c|c|c|c|c|c|c|c|c|}
\hline \multicolumn{3}{|c|}{ 時 } & \multicolumn{2}{|c|}{ 闌 (3) } & \multirow{2}{*}{$\frac{\text { 注射前 }}{78}$} & \multirow{2}{*}{$\frac{5}{72}$} & \multirow{2}{*}{$\frac{15}{72}$} & \multirow{2}{*}{$\frac{30}{92}$} & \multirow{2}{*}{$\begin{array}{l}45 \\
96\end{array}$} & \multirow{2}{*}{$\frac{60}{92}$} & \multirow{2}{*}{$\begin{array}{l}75 \\
74\end{array}$} & \multirow{2}{*}{$\frac{90}{74}$} & \multirow{2}{*}{$\frac{120}{68}$} \\
\hline 脉 & & 搏 & & 数 & & & & & & & & & \\
\hline 口 & & & & 渴 & - & \pm & + & $\#$ & 册 & $H$ & HI & \# & + \\
\hline 山 & 悸 & & 立 & 進 & - & + & \pm & \pm & \pm & \pm & - & - & - \\
\hline 呼 & & 吸 & & 数 & 18 & 18 & 18 & 20 & 20 & 18 & 16 & 16 & 16 \\
\hline 䐆 & 盖 & 腱 & 反 & 射 & - & \pm & \pm & + & + & + & + & - & - \\
\hline
\end{tabular}

「ピロカNビン」訊铪 $(0.9 \mathrm{cc})$

\begin{tabular}{|c|c|c|c|c|c|c|c|c|c|c|}
\hline 間 (分) & 注射前 & 5 & 15 & 30 & 40 & 50 & 60 & 75 & 90 & 120 \\
\hline 搏 慗 & 78 & 86 & 84 & 78 & 78 & 74 & 66 & 65 & 65 & 66 \\
\hline 液 (cc) & - & + & 20 & 50 & 25 & 25 & 20 & 20 & 20 & 20 \\
\hline 滴 狀 汗 & - & + & $\#$ & + & \pm & \pm & \pm & - & - & - \\
\hline 惡心污至嘔吐 & - & - & - & - & - & - & - & - & - & - \\
\hline 心 悸 光 進 & - & - & - & - & - & - & - & - & - & - \\
\hline 呼 吸 数 & 18 & 18 & 16 & 18 & 18 & 18 & 16 & 16 & 16 & 16 \\
\hline 尿 意 頻 数 & - & - & - & - & - & - & - & - & - & - \\
\hline 全身昫㛃 & - & $\#$ & \# & + & \pm & \pm & \pm & - & - & - \\
\hline 滕。蓋睷 反 射 & - & - & - & - & - & - & - & - & - & - \\
\hline
\end{tabular}


第 二 例

\begin{tabular}{|c|c|}
\hline 姓 名 & 青 $\mathrm{O} O$ \\
\hline 年 & 30 棫 \\
\hline 性 & 男 \\
\hline 腽军 & 56000 瓦 \\
\hline 合併症 & +2 \\
\hline
\end{tabular}

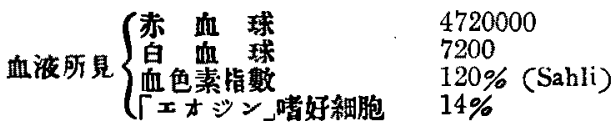

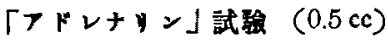

\begin{tabular}{|c|c|c|c|c|c|c|c|c|c|c|c|}
\hline 間C & (分) & 注射的 & 5 & 15 & 30 & 40 & 50 & 60 & 75 & 90 & 120 \\
\hline 搏 & 数 & 82 & 86 & 90 & 86 & 78 & 78 & 76 & 72 & 76 & 70 \\
\hline 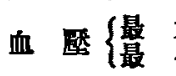 & 太 & $\begin{array}{r}145 \\
65\end{array}$ & $\begin{array}{r}158 \\
62\end{array}$ & $\begin{array}{r}150 \\
62\end{array}$ & $\begin{array}{r}140 \\
62\end{array}$ & $\begin{array}{r}138 \\
58\end{array}$ & $\begin{array}{r}133 \\
57\end{array}$ & $\begin{array}{r}130 \\
53\end{array}$ & $\begin{array}{r}130 \\
58\end{array}$ & $\begin{array}{r}125 \\
53\end{array}$ & $\begin{array}{r}128 \\
55\end{array}$ \\
\hline 呼 吸 & 数 & 20 & 20 & 20 & 20 & 20 & 20 & 20 & 22 & 20 & 21 \\
\hline 糖 & 尿 I & - & & & $\mathrm{II}+$ & & & & & & III - \\
\hline 四肢震 & 續 & - & - & - & - & - & - & - & - & - & - \\
\hline 心 悸 䒕 & 隻 & - & + & + & \pm & \pm & \pm & \pm & - & - & - \\
\hline 皮 苚 & 白 & - & - & - & - & - & - & - & - & - & $\bar{r}$ \\
\hline 皮虚效畫 & & \pm & \pm & + & + & + & + & + & + & + & \pm \\
\hline 眎蓋腱 反 & & + & + & + & $H$ & \# & $\#$ & H & 册 & \# & \# \\
\hline
\end{tabular}

「フトロビン」試驗 (0.8 cc)

\begin{tabular}{|c|c|c|c|c|c|c|c|c|c|c|c|c|c|}
\hline & 時 & & & 分) & 这射前 & 5 & 15 & 30 & 45 & 60 & 75 & 90 & 120 \\
\hline 脉 & & 搏 & & 數 & 84 & 66 & 60 & 68 & 74 & 78 & 74 & 74 & 66 \\
\hline 口 & & & & 渴 & - & - & - & - & \pm & \pm & + & + & + \\
\hline (L) & 情 & & 䒕 & 進 & - & - & - & - & - & - & \pm & \pm & - \\
\hline 呼 & & 吸 & & 数 & 22 & 22 & 22 & 22 & 22 & 22 & 22 & 20 & 22 \\
\hline 睖 & 蓋 & 腱 & 反 & 射 & + & + & H & \# & $\#$ & $\#$ & $\#$ & \# & \# \\
\hline
\end{tabular}

「ピロカルピン」武驗 $(0.8 \mathrm{cc})$

\begin{tabular}{|c|c|c|c|c|c|c|c|c|c|c|}
\hline 間(分) & 注射前 & 5 & 15 & 30 & 40 & 50 & 60 & 75 & 90 & 120 \\
\hline 持数 & 69 & 86 & 88 & 92 & 80 & 78 & 72 & 70 & 66 & 64 \\
\hline 㳸 (cc) & - & - & 20 & 35 & 35 & 15 & 20 & 15 & - & - \\
\hline 滴 狀 發 汗 & - & + & H & \# & \# & + & - & - & - & - \\
\hline 惡心乃至嘔吐 & - & - & - & - & - & - & - & - & - & - \\
\hline 心梅 淮 & - & - & - & + & \pm & \pm & - & - & - & - \\
\hline 呼 吸 数 & 21 & 23 & 22 & 24 & 24 & 22 & 22 & 20 & 20 & 20 \\
\hline 尿 頙 数 & - & - & - & - & - & - & - & - & - & - \\
\hline 全身灼器感 & - & + & \# & $H$ & + & \pm & - & - & - & - \\
\hline 膝蓋践 反射 & + & $H$ & $\#$ & 曲 & 卅 & \# & \# & \# & \# & \# \\
\hline
\end{tabular}


第三例
姓名青 一枝
年 鮯 12 淢
㤬
女
體重 43400 瓦
合併定 ナシ
診 断十二指晹蟲病

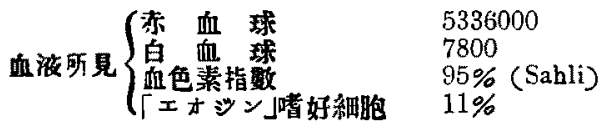

「アドレ+タン」試騷 (0.4cc)

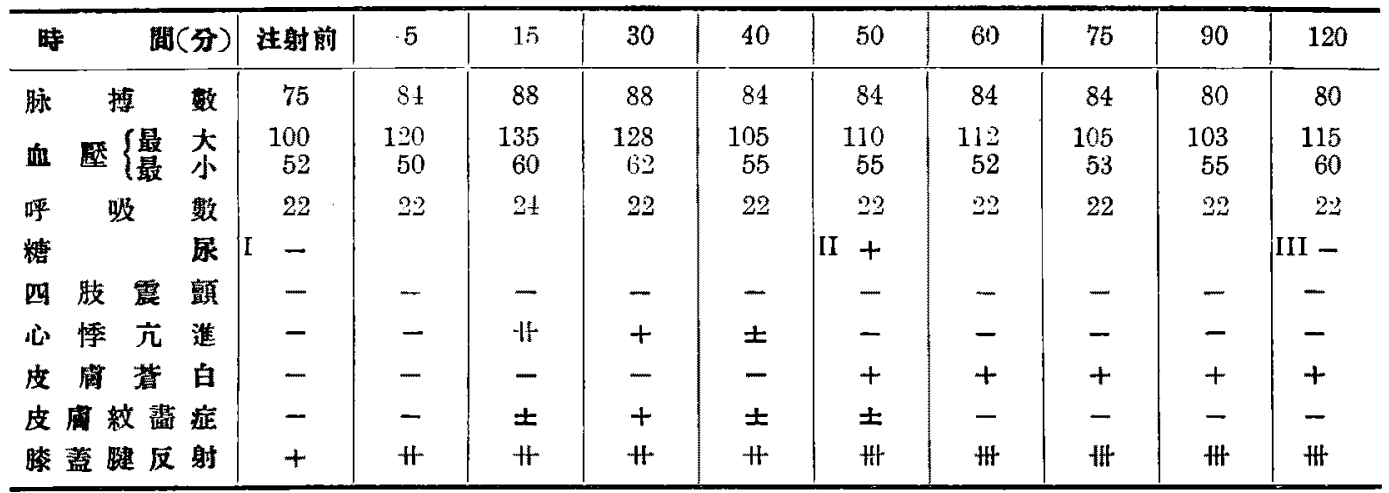

「フトロビン」試驗 (0.4cc)

\begin{tabular}{|c|c|c|c|c|c|c|c|c|c|c|c|c|c|}
\hline \multicolumn{3}{|c|}{ 時 } & \multicolumn{2}{|c|}{ 間 (分) } & 注射前 & 5 & 15 & 30 & 45 & 60 & 75 & 90 & 120 \\
\hline 腹 & & 搏 & & 数 & 57 & 75 & 67 & 88 & 12 & 90 & 80 & 76 & 74 \\
\hline 口 & & & & 渴 & - & - & + & tt & HH & $H$ & + & + & \pm \\
\hline 心 & 悸 & & 䒕 & 進 & - & - & + & + & It & H & Ht & - & - \\
\hline 唓 & & 吸 & & 数 & 21 & 21 & 25 & 22 & 22 & 20 & 20 & 21 & 203 \\
\hline 䇧 & 蓋 & 犍 & 反 & 射 & + & \# & 世 & 卅 & H & $H$ & HIt & \# & \# \\
\hline
\end{tabular}

「ビロカทピン」試驗 $(0.4 c c)$

\begin{tabular}{|c|c|c|c|c|c|c|c|c|c|c|}
\hline 間(分) & 注射前 & 5 & 15 & 30 & 40 & 50 & 60 & 75 & 90 & 120 \\
\hline 脉搏 & 82 & 70 & 78 & 74 & 74 & 72 & 74 & 74 & 64 & 64 \\
\hline 唾 & - & - & 5 & 20 & 15 & 5 & - & - & - & - \\
\hline 㯵 狀 發 汗 & - & + & + & + & + & \pm & - & - & - & - \\
\hline 瑟心乃至嘔吨 & - & - & + & + & \pm & \pm & - & - & - & - \\
\hline 心 悸 穴 進 & - & - & - & - & - & - & - & - & - & - \\
\hline 呼 吸 數 & 20 & 22 & 20 & 20 & 20 & 20 & 20 & 20 & 18 & 18 \\
\hline 尿 意 頻 数 & - & - & - & - & - & - & - & - & - & - \\
\hline 全身灼熱感 & - & + & + & + & + & + & - & - & - & - \\
\hline 㮏蓋腱 反射 & + & $H$ & \# & 世 & \# & $\mathrm{H}^{+}$ & H & $H$ & H & 世 \\
\hline
\end{tabular}


第四例
姓名 笠 00 太
年 24 路
性男
體重 55500 瓦
合併虚 ナン
診

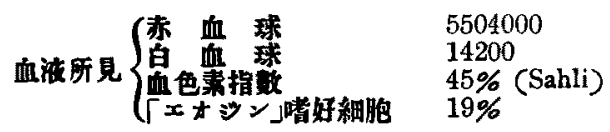

「フドレナン」試驗 $(0.8 \mathrm{cc})$

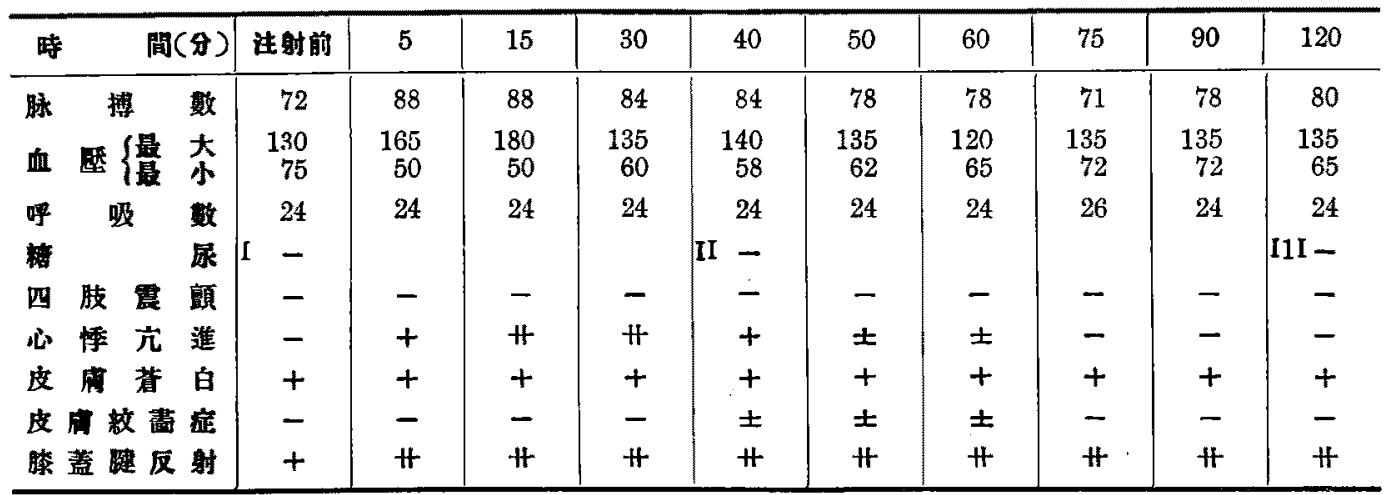

「アトロヒン」誠驗 $(08 \mathrm{cc})$

\begin{tabular}{|c|c|c|c|c|c|c|c|c|c|c|c|c|c|}
\hline \multicolumn{3}{|c|}{ 時 } & \multicolumn{2}{|c|}{ 間（分） } & \multirow{2}{*}{$\frac{\text { 注射前 }}{80}$} & \multirow[b]{2}{*}{80} & \multirow{2}{*}{$\begin{array}{l}15 \\
78\end{array}$} & \multirow{2}{*}{$\frac{30}{82}$} & \multirow{2}{*}{$\begin{array}{l}45 \\
82\end{array}$} & \multirow{2}{*}{$\begin{array}{l}60 \\
90\end{array}$} & \multirow{2}{*}{$\begin{array}{l}75 \\
88\end{array}$} & \multirow{2}{*}{$\frac{90}{88}$} & \multirow{2}{*}{$\begin{array}{r}120 \\
86\end{array}$} \\
\hline 䶼 & & 搏 & & 數 & & & & & & & & & \\
\hline a & & & & 混 & - & + & $\#$ & $H$ & H & $H$ & + & \pm & - \\
\hline 心 & 悸 & & 䒕 & 隻 & - & + & \# & \# & $\mathrm{H}$ & $\#$ & + & \pm & - \\
\hline 吗 & & 吸 & & 數 & 21 & 20 & 24 & 24 & 24 & 22 & 22 & 22 & 22 \\
\hline 滕 & 蓋 & 腱 & 反 & 射 & + & $\#$ & H & 曲 & W & $\mathrm{H}^{-}$ & H & \# & H \\
\hline
\end{tabular}

「ヒロカルヒン」試稌（1.0cc）

\begin{tabular}{|c|c|c|c|c|c|c|c|c|c|c|}
\hline 時 間(牙) & 注射前 & 5 & 15 & 30 & 40 & 50 & 60 & 75 & 90 & 120 \\
\hline 搏數 & 68 & 78 & 80 & 80 & 82 & 70 & 68 & 70 & 70 & 62 \\
\hline 波(cc) & - & + & 15 & 15 & 10 & 20 & 15 & 20 & 20 & 20 \\
\hline 满 狀 就 汗 & - & - & - & + & + & + & + & \pm & $\neq$ & - \\
\hline 面心乃至嘔吐 & - & - & - & - & - & - & - & - & - & - \\
\hline 心标 六 & - & + & $\#$ & + & + & + & \pm & - & - & - \\
\hline 吗 吸 数 & 18 & 18 & 20 & 20 & 20 & 19 & 20 & 18 & 20 & 18 \\
\hline 尿 意 頻 票 & - & - & - & - & + & + & + & + & \pm & - \\
\hline 全身昫熱感 & + & + & $\#$ & $\#$ & H & H & + & - & - & - \\
\hline 膫蓋睷 反射 & + & + & \# & \# & $H$ & + & + & + & + & + \\
\hline
\end{tabular}


策

五.

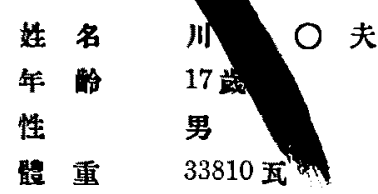

合併症 +2

診 断 十二指渴蛅病

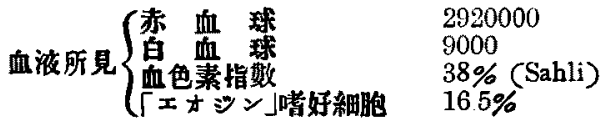

「フドレ+】ン」陚驗 $(0.5 \mathrm{cc})$

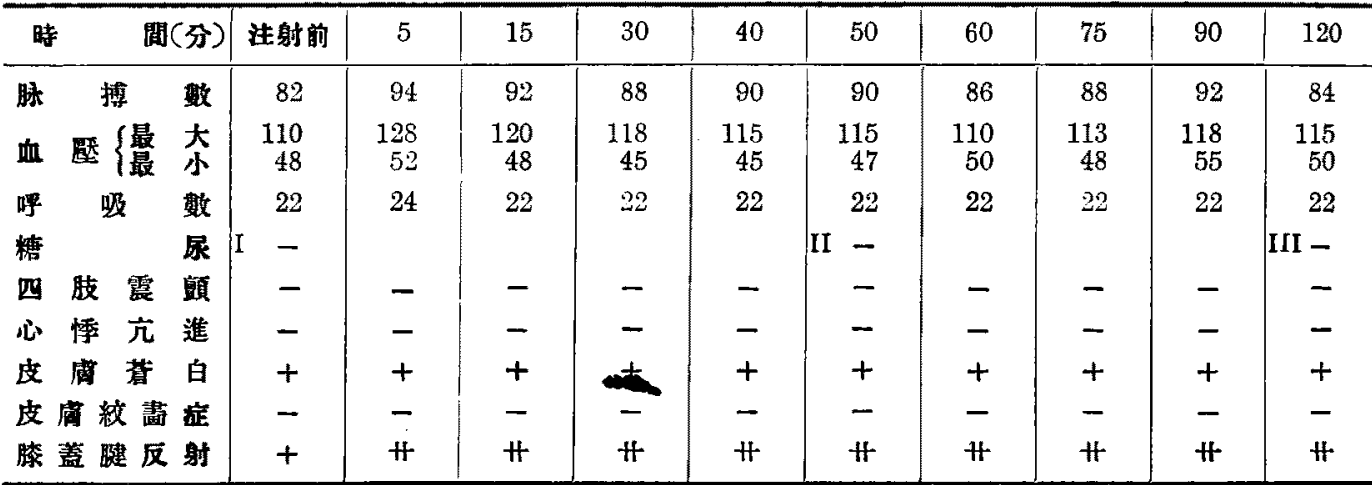

「テトロビン」武羷 $(0.5 \mathrm{cc})$

\begin{tabular}{|c|c|c|c|c|c|c|c|c|c|c|c|c|c|}
\hline \multicolumn{3}{|c|}{ 時 } & \multicolumn{2}{|c|}{ 間（分） } & 注財前 & 5 & 15 & 30 & 45 & 60 & 75 & 90 & 120 \\
\hline 脉 & & 搏 & & 耧 & 75 & 77 & 81 & 88 & 88 & 83 & 73 & 78 & 67 \\
\hline 口 & & & & 渴 & - & - & + & + & + & H & If & H & H \\
\hline 心 & 㥪 & & 立 & 進 & - & + & - & - & - & - & - & - & - \\
\hline 踽 & & 吸 & & 呚 & 22 & 23 & 22 & 24 & 23 & 24 & 23 & 23 & 22 \\
\hline 䋚 & 蓋 & 睷 & 反 & 射 & + & + & + & \# & $\#$ & H & $H$ & $\#$ & $\#$ \\
\hline
\end{tabular}

「ヒロカロヒン」武驗 $(0.5 c c)$

\begin{tabular}{|c|c|c|c|c|c|c|c|c|c|c|}
\hline 間(分) & 注射前 & 5 & 15 & 30 & 40 & 50 & 60 & 75 & 90 & 120 \\
\hline 搏 数 & 60 & 72 & 78 & 80 & 80 & 82 & 80 & 72 & 72 & 68 \\
\hline 波 (cc) & - & - & 15 & 25 & 15 & 15 & 10 & 7 & 10 & 20 \\
\hline 滴 狀 發 汗 & - & - & - & - & - & - & - & - & - & - \\
\hline 㵙心乃至嘔昍 & - & - & - & 一 & 一 & - & - & - & 一 & 一 \\
\hline 心 悸 䒕 進 & - & - & - & - & - & - & - & - & - & 一 \\
\hline 呼 吸 & 21 & 20 & 20 & 19 & 18 & 18 & 20 & 20 & 18 & 18 \\
\hline 尿澺頻 數 & - & - & - & 一 & - & - & - & - & - & - \\
\hline 全身灼熱感 & - & - & - & - & - & - & - & 一 & 一 & - \\
\hline 滕盖腱 反射 & + & $H$ & $\#$ & H & 曲 & H & \# & HI & \# & Ht \\
\hline
\end{tabular}


第六例

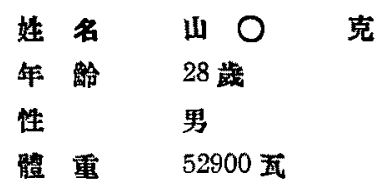

合併店 +2

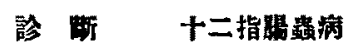

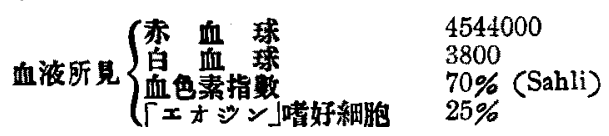

「フドレナリン」武猃 $(0.6 \mathrm{cc})$

\begin{tabular}{|c|c|c|c|c|c|c|c|c|c|c|c|}
\hline 闌 & (5t) & 注射前 & 5 & 15 & 30 & 40 & 50 & 60 & 75 & 90 & 120 \\
\hline 脉搏 & 㷮 & 71 & 91 & 100 & 85 & 84 & 79 & 78 & 78 & 76 & 72 \\
\hline 血 笙 㵊 & 杂 & $\begin{array}{r}134 \\
66\end{array}$ & $\begin{array}{r}140 \\
65\end{array}$ & $\begin{array}{r}17.2 \\
66\end{array}$ & $\begin{array}{r}133 \\
67\end{array}$ & $\begin{array}{r}130 \\
67\end{array}$ & $\begin{array}{r}128 \\
70\end{array}$ & $\begin{array}{r}120 \\
67\end{array}$ & $\begin{array}{r}115 \\
67\end{array}$ & $\begin{array}{r}110 \\
67\end{array}$ & $\begin{array}{r}112 \\
67\end{array}$ \\
\hline 睘吸 & 䅹 & 16 & 18 & 17 & 18 & 18 & .16 & 16 & 17 & 16 & 16 \\
\hline 四 肢 震 & 䫘 & - & - & + & \pm & \pm & \pm & - & - & - & - \\
\hline 心 悸 穴 & 萑 & \pm & \pm & + & + & \pm & \pm & \pm & \pm & \pm & \pm \\
\hline 度 倣 莒 & 白 & + & + & \pm & \pm & & \pm & \pm & \pm & \pm & \pm \\
\hline 皮席紋 畵 & 症 & - & - & \pm & \pm & - & - & - & - & - & - \\
\hline 滕盖睷 反 & & + & \# & H & H & \# & $\#$ & \# & + & + & + \\
\hline
\end{tabular}

「フトロビン」試呀 $(0.6 c c)$

\begin{tabular}{|c|c|c|c|c|c|c|c|c|c|c|c|c|c|}
\hline & \multicolumn{2}{|l|}{ 時 } & \multicolumn{2}{|c|}{ 間 (分) } & 注射前 & 5 & 15 & 30 & 45 & 60 & 75 & 90 & 120 \\
\hline 脉 & & 婹 & & 數 & 78 & 67 & 74 & 73 & 77 & 78 & 67 & 66 & 73 \\
\hline 口 & & & & 渴 & + & + & $H$ & $H$ & $\#$ & H & H & $H$ & H \\
\hline$心$ & 悸 & & 六 & 進 & - & - & \pm & + & + & + & + & + & \pm \\
\hline 喓 & & 吸 & & 数 & 18 & 16 & 16 & 18 & 18 & 18 & 15 & 15 & 15 \\
\hline 滕 & 盒 & 睷 & 反 & 射 & + & + & + & + & + & + & \pm & \pm & \pm \\
\hline
\end{tabular}

「ピロカルヒン」試驗 $(0.6 \mathrm{cc})$

\begin{tabular}{|c|c|c|c|c|c|c|c|c|c|c|}
\hline 時間(分) & 注射前 & 5 & 15 & 30 & 40 & 50 & 60 & 75 & 90 & 120 \\
\hline 脉 搏 酷 & 75 & 83 & 100 & 65 & 85 & 77 & 78 & 77 & 77 & 80 \\
\hline 唾 浓 (cc) & - & + & 20 & 30 & 25 & 25 & 15 & 18 & 18 & 10 \\
\hline 滴 狀 發 汗 & - & - & + & + & - & - & - & - & - & - \\
\hline 惡心乃至殹吐 & - & - & - & - & - & - & - & - & - & - \\
\hline 心悸 方 進 & - & + & + & \pm & \pm & \pm & - & - & - & - \\
\hline 吗吸 敏 & 17 & 16 & 19 & 18 & 18 & 18 & 18 & 16 & 18 & 17 \\
\hline 尿 澺類 數 & - & - & - & - & - & - & - & - & - & - \\
\hline 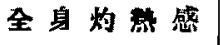 & - & + & + & + & - & - & - & - & - & - \\
\hline 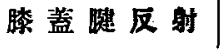 & + & \pm & + & + & $\#$ & $\#$ & + \pm & + \pm & + & + \\
\hline
\end{tabular}


第七例

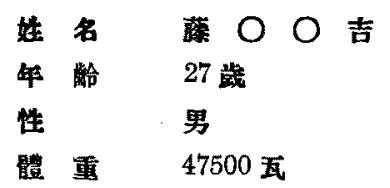

合併店 ナン

䛦 断 十二指睗䖵病

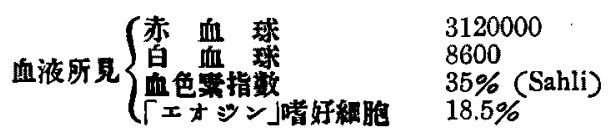

「フドレナリン」試䟻 $(0.6 \mathrm{cc})$

\begin{tabular}{|c|c|c|c|c|c|c|c|c|c|c|c|}
\hline 時 & (分) & 注射前 & 5 & 15 & 30 & 40 & 50 & 60 & 75 & 90 & 120 \\
\hline 搏 & 潅 & 55 & 65 & 68 & 73 & 69 & 63 & 57 & 64 & 65 & 58 \\
\hline 血 㖤 $\left\{\begin{array}{l}\text { 最 } \\
\text { 最 }\end{array}\right.$ & 奆 & $\begin{array}{r}112 \\
67\end{array}$ & $\begin{array}{r}145 \\
67\end{array}$ & $\begin{array}{r}142 \\
66\end{array}$ & $\begin{array}{r}120 \\
67\end{array}$ & $\begin{array}{r}115 \\
67\end{array}$ & $\begin{array}{r}115 \\
67\end{array}$ & $\begin{array}{r}105 \\
67\end{array}$ & $\begin{array}{l}99 \\
67\end{array}$ & $\begin{array}{l}98 \\
67\end{array}$ & $\begin{array}{l}94 \\
67\end{array}$ \\
\hline 吸 & 数 & 21 & 24 & 24 & 24 & 24 & 22 & 16 & 18 & 20 & 23 \\
\hline 糖 & 尿 & - & & & & II - & & & & & III - \\
\hline 四 肢 震 & 頭 & + & $H$ & \# & \# & H & \# & $\#$ & $\#$ & + & + \\
\hline 心悸 䒕 & 進 & - & + & $H$ & $\#$ & \# & \pm & \pm- & - & - & - \\
\hline 皮 萠 腒 & 白 & + & H & $\#$ & $H$ & $H$ & + & + & + & + & + \\
\hline 皮虑紋 劃 & & - & + & + & + & + & \pm & \pm- & - & - & - \\
\hline 滕蓋硨 反 & & + & \# & $\#$ & \# & $\#$ & + & + & + & + & + \\
\hline
\end{tabular}

「アトロビン」試弨 $(0.6 \mathrm{cc})$

\begin{tabular}{|c|c|c|c|c|c|c|c|c|c|c|c|c|c|}
\hline & 時 & & & 分) & 注射前 & 5 & 15 & 30 & 45 & 60 & 75 & 90 & 120 \\
\hline 脉 & & 掼 & & 數 & 65 & 60 & 61 & 63 & 60 & 63 & 65 & 59 & 58 \\
\hline 口 & & & & 渴 & - & - & + & + & + & + & + & + & + \\
\hline 心 & 悸 & & 䒕 & 進 & - & - & \pm & - & - & - & - & - & - \\
\hline 哹 & & 吸 & & 数 & 18 & 23 & 19 & 19 & 21 & 19 & 22 & 24 & 23 \\
\hline 滕 & 蓋 & 踺 & 反 & 射 & $\#$ & $H$ & \# & $H$ & H & H & $\#$ & $\#$ & $\#$ \\
\hline
\end{tabular}

「ヒロカルヒン」試鸦 $(0.6 \mathrm{cc})$

\begin{tabular}{|c|c|c|c|c|c|c|c|c|c|c|}
\hline 時睛(分) & 注射觔 & 5 & 15 & 30 & 40 & 50 & 60 & 75 & 90 & 120 \\
\hline 搏数 & 64 & 69 & 75 & 69 & 68 & 66 & 67 & 66 & 64 & 62 \\
\hline 浓(cc) & - & + & 20 & 18 & 15 & 10 & 10 & 8 & 5 & - \\
\hline 滴 狀 發 汗 & - & - & \pm & \pm & - & - & - & - & - & - \\
\hline 惡心乃至嘔吐 & - & - & - & - & - & - & - & - & - & - \\
\hline 心悸方 萑 & - & - & - & - & - & - & - & - & - & - \\
\hline 呼 吸 数 & 22 & 20 & 21 & 23 & 22 & 20 & 23 & 21 & 20 & 24 \\
\hline 尿意類 数 & - & - & - & - & - & - & - & - & - & - \\
\hline 全身灼熱感 & - & \pm & + & \pm & - & - & - & - & - & - \\
\hline 䐂蓋 腱反射 & + & + & $t \pm$ & + \pm & $\#$ & $\#$ & + \pm & + \pm & + \pm & + \\
\hline
\end{tabular}


第 八例

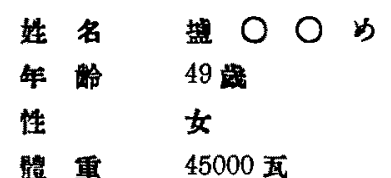

體重 45000 成

合併定 ナシ

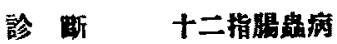

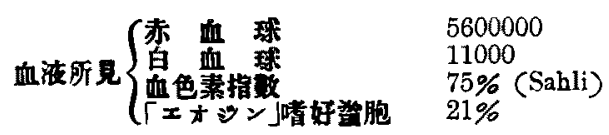

「フトレ+ンン」試驗 $(0.5 \mathrm{cc})$

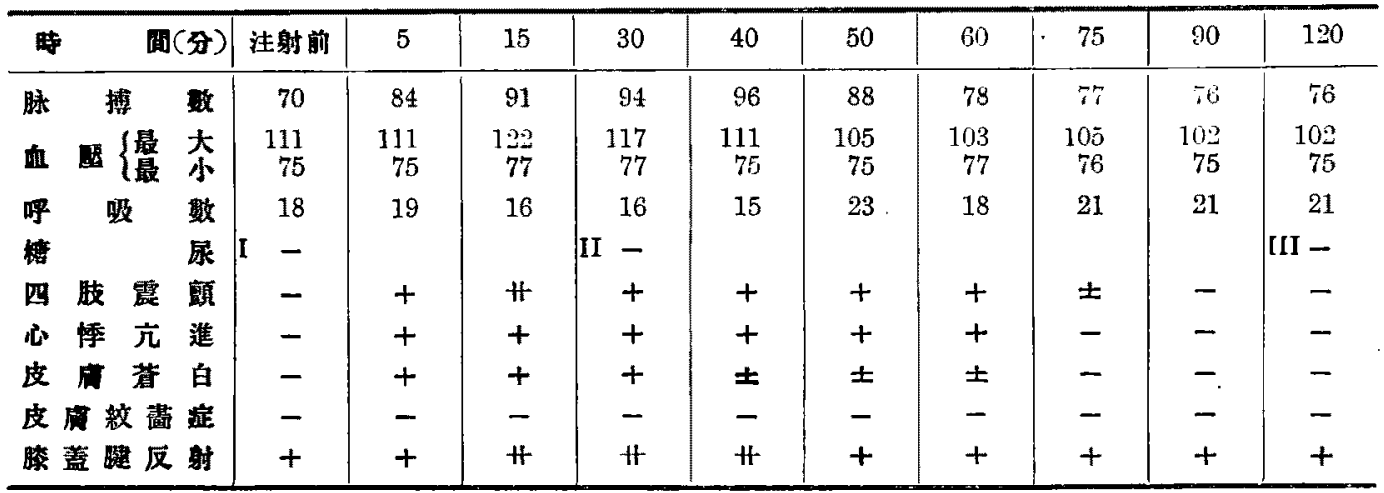

「アトロビン」試驗 $(0.5 \mathrm{cc})$

\begin{tabular}{|c|c|c|c|c|c|c|c|c|c|c|c|c|c|}
\hline \multicolumn{3}{|c|}{ 時 } & \multicolumn{2}{|c|}{ 間 (分) } & \multirow{2}{*}{$\frac{\text { 伡影前 }}{58}$} & \multirow{2}{*}{$\frac{5}{60}$} & \multirow{2}{*}{$\frac{15}{58}$} & \multirow{2}{*}{$\frac{30}{66}$} & \multirow{2}{*}{$\frac{45}{70}$} & \multirow{2}{*}{$\frac{60}{64}$} & \multirow{2}{*}{$\frac{75}{84}$} & \multirow{2}{*}{$\frac{90}{68}$} & \multirow{2}{*}{$\begin{array}{l}120 \\
66\end{array}$} \\
\hline 㮯 & & 搏 & & 部 & & & & & & & & & \\
\hline 口 & & & & 温 & - & - & + & + & + & + & + & + & + \\
\hline 心 & 悸 & & 䒕 & 進 & - & - & - & + & + & \pm & - & - & - \\
\hline 呼 & & 吸 & & 數 & 20 & 16 & 17 & 25 & 27 & 26 & 28 & 17 & 20 \\
\hline 滕 & 盖 & 㽣 & 反 & 射 & + & + & + & $H$ & $\#$ & + & + & + & + \\
\hline
\end{tabular}

「ピロカルピン」試驗 $(0.5 \mathrm{cc})$

\begin{tabular}{|c|c|c|c|c|c|c|c|c|c|c|}
\hline 时 间(分) & 注射的 & 5 & 15 & 30 & 40 & 50 & 60 & 75 & 90 & 120 \\
\hline 蒸 搏 稤 & 61 & 76 & 73 & 72 & 71 & 75 & 77 & 68 & 68 & 73 \\
\hline 㗕 浓 (cc) & - & + & 25 & 25 & 20 & 17 & 15 & 13 & 10 & 10 \\
\hline 滴 狀 發 汗 & - & - & - & - & - & - & - & \pm & \pm & \pm \\
\hline 惡心乃至嘔吐 & - & - & - & + & \pm & - & - & - & - & - \\
\hline 心 悸 元 進 & - & - & - & - & - & - & - & - & - & - \\
\hline 噃 吸 & 21 & 21 & 18 & 20 & 20 & 25 & 21 & 20 & 21 & 21 \\
\hline 尿 澺頻 & - & - & - & - & - & - & - & - & - & - \\
\hline 全身灼熱感 & - & - & - & - & - & + & + & + & + & + \\
\hline 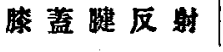 & + & + & + & + & \# & + \pm & + \pm & + \pm & + & + \\
\hline
\end{tabular}


第 九 例
蛙 名 松 00 -
年 踰 60 皷
性
男
體重 43200 瓦
合併庭 $+*$
訅 断 十二指晹蛅病

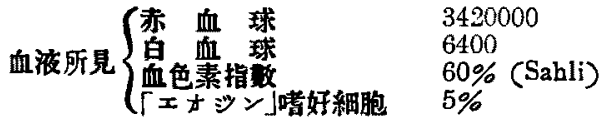

「フドレナリン」試驗 $(0.6 \mathrm{cc})$

\begin{tabular}{|c|c|c|c|c|c|c|c|c|c|c|c|c|}
\hline 時 & 間C & (3) & 注射前 & 5 & 15 & .80 & 40 & 50 & 60 & 75 & 90 & 120 \\
\hline & 撚 & 數 & 78 & 60 & 66 & 22 & 72 & 72 & 72 & 78 & 78 & 78 \\
\hline & 䐴 $\left\{\begin{array}{l}\text { 最 } \\
\text { 最 }\end{array}\right.$ & 太 & $\begin{array}{l}95 \\
40\end{array}$ & $\begin{array}{r}135 \\
43\end{array}$ & $\begin{array}{r}110 \\
43\end{array}$ & $\begin{array}{r}100 \\
42\end{array}$ & $\begin{array}{l}95 \\
43\end{array}$ & $\begin{array}{l}91 \\
42\end{array}$ & $\begin{array}{l}92 \\
42\end{array}$ & $\begin{array}{l}92 \\
42\end{array}$ & $\begin{array}{l}92 \\
42\end{array}$ & $\begin{array}{l}88 \\
42\end{array}$ \\
\hline 㭔 & 吸 & 数 & 24 & 21 & 24 & 21 & 24 & 24 & 24 & 21 & 24 & 21 \\
\hline 傏 & & 辰 & - & & & & II - & & & & & III - \\
\hline & 肢 震 & 䫓 & - & 枝 & + & + & + & + & + & + & + & + \\
\hline & 悸 元 & 淮 & - & \# & + & - & - & - & - & - & - & - \\
\hline & 虑 荅 & & - & - & - & - & - & - & - & - & - & - \\
\hline & 盧絞苚 & & - & - & - & - & - & - & - & - & - & - \\
\hline & 盖 踺 反 & & \pm & + & \pm & \pm & \pm & \pm & \pm & \pm & \pm & \pm \\
\hline
\end{tabular}

「アトロヒン」武獫 (0.6cc)

\begin{tabular}{|c|c|c|c|c|c|c|c|c|c|c|c|c|c|}
\hline & 時 & & & (分) & 注射前 & 5 & 15 & 30 & 45 & 60 & 75 & 90 & 120 \\
\hline 脉 & & 搏 & & 嘈 & 72 & 72 & 76 & 76 & 80 & 79 & 78 & 78 & 73 \\
\hline 口 & & & & 渴 & + & + & + & + & H & $\#$ & $\#$ & $\#$ & \# \\
\hline 心 & 情 & & 艺 & 進 & - & - & - & - & + & + & + & \pm & \pm \\
\hline 喓 & & 吸 & & 数 & 24 & 24 & 24 & 27 & 27 & 24 & 24 & 24 & 24 \\
\hline 滕 & 蓋 & 腱 & 反 & 射 & \pm & \pm & \pm & \#t & it & \# & \# & H & \# \\
\hline
\end{tabular}

「ヒロカルヒン」試驗 $(0.6 \mathrm{cc})$

\begin{tabular}{|c|c|c|c|c|c|c|c|c|c|c|}
\hline 時閏(分) & 注射前 & 5 & 15 & 30 & 40 & 50 & 60 & 75 & 90 & 120 \\
\hline 脉搏 數 & 71 & 66 & 70 & 75 & 66 & 72 & 65 & 61 & 68 & 62 \\
\hline 浓 (cc) & - & - & 2 & 20 & 20 & 20 & 15 & 8 & 2 & - \\
\hline 滴 狀 汗 & - & - & - & - & - & - & - & - & - & - \\
\hline 惡心乃至嘔吐 & - & - & - & + & - & - & - & - & - & - \\
\hline 山悸䒕進 & - & - & - & + & + & \pm & \pm & \pm & - & - \\
\hline 哹 吸 数 & 23 & 18 & 17 & 19 & 18 & 18 & 18 & 19 & 20 & 20 \\
\hline 尿 意 頻 數 & - & - & - & + & + & + & + & + & + & \pm \\
\hline 全身灼熱感 & - & - & - & \pm & - & - & - & - & - & - \\
\hline 睦蓋腱 反射 & + & + & + & + & + & + \pm & + \pm & + & + & + \\
\hline
\end{tabular}


第十 例

\begin{tabular}{|c|c|}
\hline 姓 名 & 藤 0 \\
\hline 赫 & 19 琖 \\
\hline 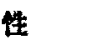 & 男 \\
\hline 重 & 43900 瓦 \\
\hline 併应 & ナシ \\
\hline
\end{tabular}

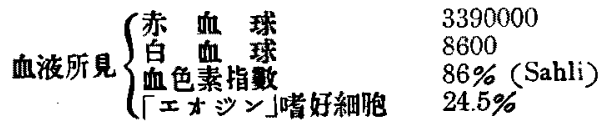

「フドレナタン」試䠯 $(0.5 \mathrm{cc})$

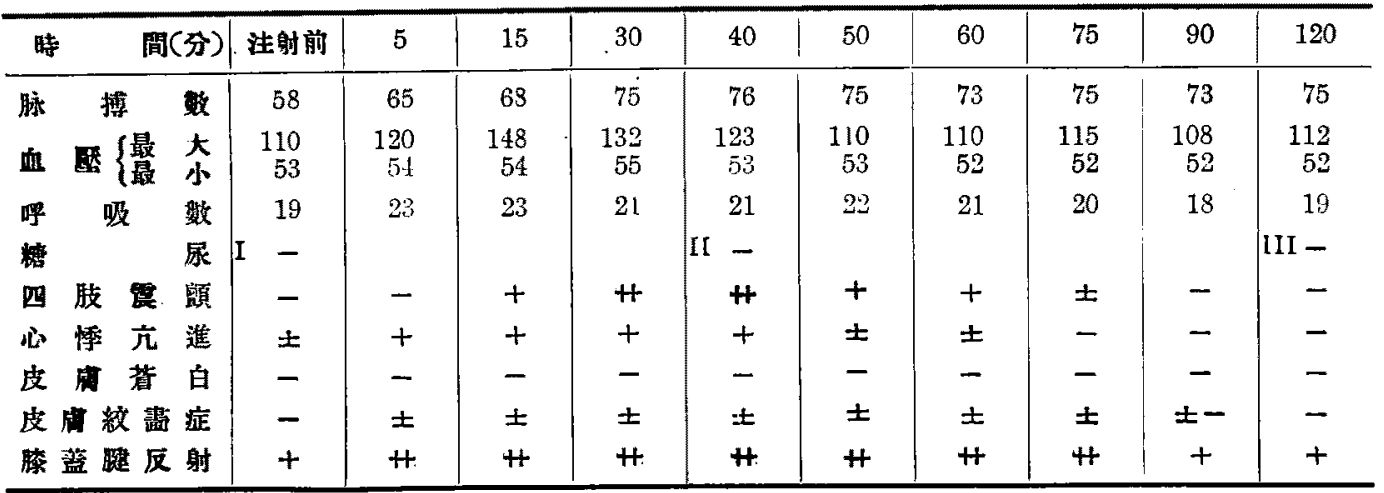

「フトロピン」武输 (0.5c0)

\begin{tabular}{|c|c|c|c|c|c|c|c|c|c|c|c|c|c|}
\hline & 時 & & & (分) & 注射前 & 5 & 15 & 30 & 45 & 60 . & 75 & 90 & 120 \\
\hline 䀣 & & 搏 & & 数 & 69 & 60 & 62 & 61 & 72 & 71 & 70 & 70 & 66 \\
\hline 口 & & & & 温 & - & - & \pm & \pm & + & + & + & + & \pm \\
\hline 心 & 慓 & & 亢 & 進 & \pm & \pm & \pm & \pm & \pm & + & + & + & \pm \\
\hline 㨼 & & 吸 & & 数 & 18 & 19 & $\hat{2} 1$ & 18 & 20 & 19 & 18 & 18 & 18 \\
\hline 㳟 & 蓋 & 政 & 反 & 射 & + & $H$ & $H$ & $H \pm$ & $\#$ & + \pm & + \pm & + \pm & + \\
\hline
\end{tabular}

「ピロカネピン」趾驗 (0.5cc)

\begin{tabular}{|c|c|c|c|c|c|c|c|c|c|c|}
\hline 間(分) & 注射前 & 5 & 15 & 30 & 40 & 50 & 60 & 75 & 90 & 120 \\
\hline 搏数 & 62 & 70 & 67 & 72 & 71 & 68 & 68 & 66 & 66 & 62 \\
\hline 波 (cc) & - & + & 15 & 45 & 25 & 30 & 30 & 25 & 20 & 20 \\
\hline 滴 狀 發 汗 & - & - & H & + & \pm & \pm & \pm & - & - & - \\
\hline 惡心乃至嘔吐 & \pm & \pm & + & + & - & \pm & \pm & \pm & \pm & \pm \\
\hline 心 悸 穴 進 & - & - & + & + & \pm & \pm & - & - & - & - \\
\hline 哱 吸 数 & 21 & 18 & 21 & 18 & 20 & 20 & 20 & 18 & 18 & 18 \\
\hline 尿 & - & - & - & + & + & - & - & - & - & - \\
\hline 全身灼熱感 & - & \pm & + & + & \pm & \pm & - & - & - & - \\
\hline 睖 蓋 睷 反射 & + & + & + & $H$ & $H$ & $\#$ & $H$ & + \pm & + \pm & + \pm \\
\hline
\end{tabular}


第十一例

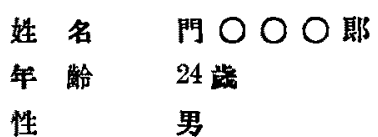

重 52900 瓦

合併庭音

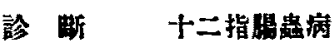

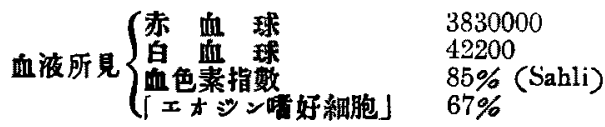

「アドレナツン」試驗 (0.9cc)

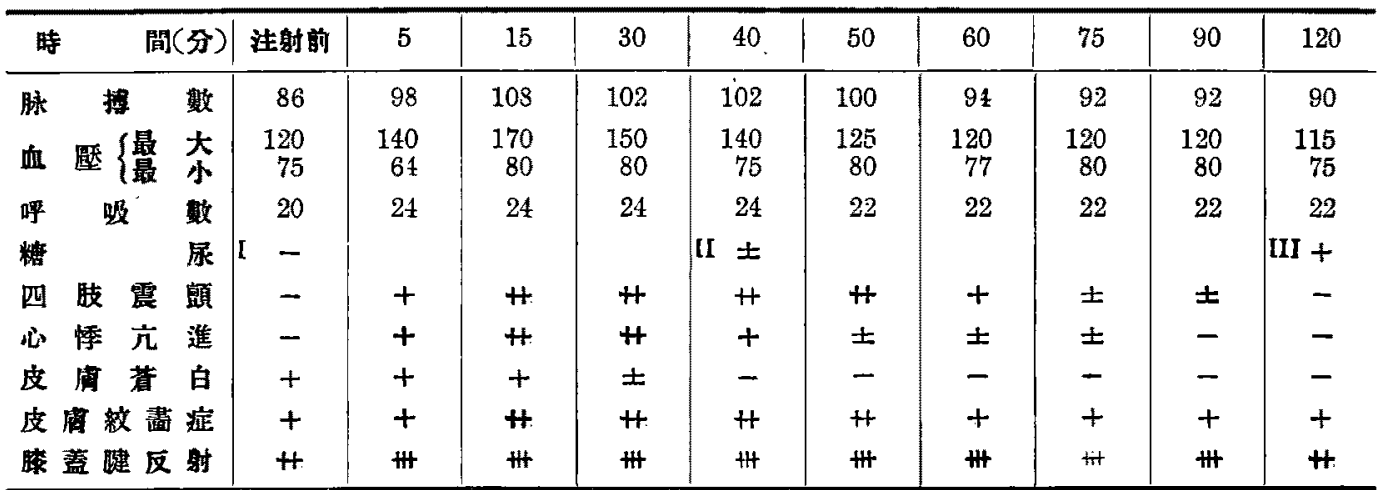

「フトロピン」試驗 $(0.9 \mathrm{cc})$

\begin{tabular}{|c|c|c|c|c|c|c|c|c|c|c|c|c|c|}
\hline \multicolumn{3}{|c|}{ 時 } & \multicolumn{2}{|c|}{ 間（分） } & 注菂前 & 5 & 15 & 30 & 45 & 60 & 75 & 90 & 120 \\
\hline 滕 & & 搏 & & 效 & 94 & 96 & 96 & 100 & 100 & 96 & 92 & 90 & 86 \\
\hline 口 & & & & 渴 & - & + & - & $H$ & $H$ & Ht & \# & Ht & 4 \\
\hline i & 㻑 & & 立 & 進 & - & \pm & \pm & + & $H$ & $H$ & + & + & \pm \\
\hline 呼 & & 吸 & & 数 & 20 & 22 & 22 & 22 & 22 & 22 & 22 & 22 & 22 \\
\hline 溙 & 盖 & 踺 & 反 & 射 & $H$ & $H$ & $H$ & 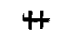 & 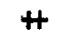 & $H$ & H & 4 & 4 \\
\hline
\end{tabular}

「ビロカピン」武碳 (0.9cc)

\begin{tabular}{|c|c|c|c|c|c|c|c|c|c|c|}
\hline 時間(分) & 注射前 & 5 & 15 & 30 & 40 & 50 & 60 & 75 & 90 & 120 \\
\hline 脉 搏 数 & 74 & 74 & 80 & 84 & 80 & 84 & 76 & 72 & 74 & 74 \\
\hline 液 (cc) & \pm & + & 5 & + & - & + & + & + & - & - \\
\hline 滴 狀 汗 & - & 一 & - & - & - & - & - & - & - & - \\
\hline 琶心乃至嘔吐 & - & - & - & - & - & - & - & - & - & - \\
\hline 心悸 䒕 淮 & - & - & - & + & + & \pm & \pm & \pm & + & \pm \\
\hline 呼 吸 數 & 20 & 20 & 22 & 22 & 22 & 22 & 22 & 22 & 22 & 22 \\
\hline 厡 澺 類 數 & - & - & 一 & 一 & 一 & - & - & $\rightarrow$ & - & - \\
\hline 全身灼䓡感 & - & - & - & - & - & - & - & - & - & - \\
\hline 溙蓋腱 反射 & $H$ & H & $H$ & $H$ & H & \# & $H$ & $H$ & H & $\Psi$ \\
\hline
\end{tabular}


今前記男 9 例，女 2 例，計 11 例／檢査成綪 7 總括表記スレバ炎ノ如シ.

\begin{tabular}{|c|c|c|c|c|c|}
\hline 例 & 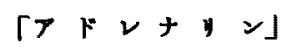 & 「ヒロかルピン」 & $\Gamma \gamma$ & $r$ & 口 \\
\hline 1 & \# & $\#$ & & & + \\
\hline 2 & + & \# & & & + \\
\hline 3 & + & H & & & H \\
\hline 4 & + & \# & & & $\#$ \\
\hline 5 & - & + & & & + \\
\hline 6 & $\#$ & \# & & & \# \\
\hline .7 & + & H & & & + \\
\hline 8 & + & \# & & & + \\
\hline 9 & + & $H$ & & & $H$ \\
\hline 10 & + & Hit & & & + \\
\hline 11 & H & - & & & $H$ \\
\hline
\end{tabular}

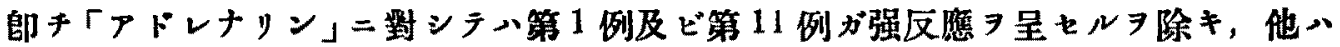

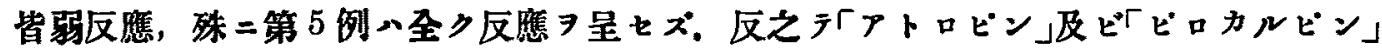
ニ對シラハ，第 11 例ガ「ビロカルビン」二全ク反應七ザルョ除キ何レモ中等度乃至弱

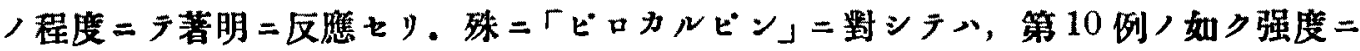
二反㤫セルヨ始メ，大多數、中等度/反應 レョリ輕ク郎チ5 例二於ラハ中等度二反應七ルモ，他ノ病例二於テッ何レモ弱反憵ナ リ.コノ結果ヨリシテエっビンダル氏等ノ言フ如ク, 植物性神經系統 $フ$ 拮抗的二交感及

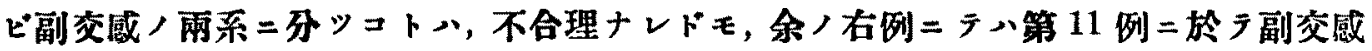
神經緊張低下二基ク交感神經緊張立進ノ狀

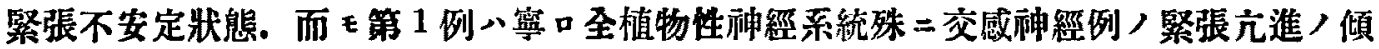
向

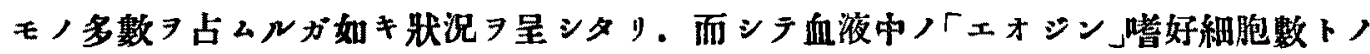
間二一定ノ關係 7 見出スコト能ハザルモ，一般二貣血ノ度强キモノ二副荠威神經緊張 不安定ノ狀態著明ナルモノ多キガ如キ観

之等ノ反應ノ意義ニッキテハ評論スルタ得ザルモ，第 11 例郎チ「エオシン」暏好紐

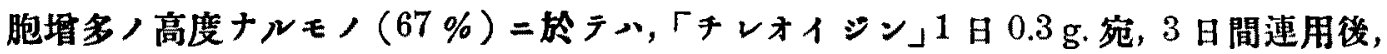

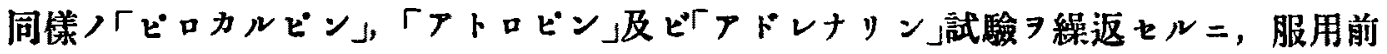
二比シ，何レモン八反應 ヨ堵シ，殊二服用前現レザリシ「ピロカルビン」反㮣ノ輕度ナ ガラ出現スルタ見タソ。師手全植物性神經系統緊張, 不安定ノ度㘿强シ，殊二迷走神

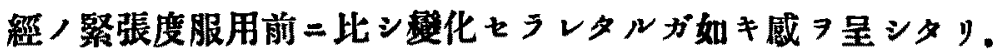


又「モルヒネ」中毒患者ニテ「ビロカルビン」ニ反應セズシテ「アトロビン」弱反應を

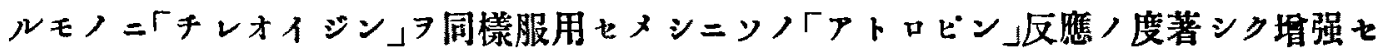
y.

又糖尿病患者二五同樣「ビロカルビン」反慰ナク，「アトロピン」及ビ「アドレナリン」 二弱反㫿七ルモノニラ「チレオイヂン」服用後同樣「アトロビン」反應强度二出現セリ。

厼ホ「バルキンソニスムス患者ノ植物性神經機能ニッキテハ，小田，角尾等諸氏，

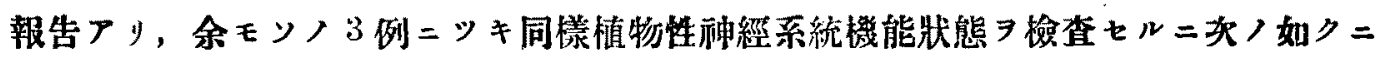

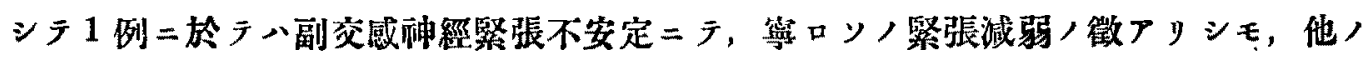
2 例ニ於テハ「アドレナリン」ニモ弱度ナガラ反篧シ，且「ピロカルピン」最モ著明:

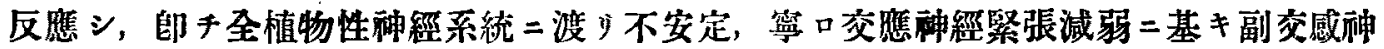

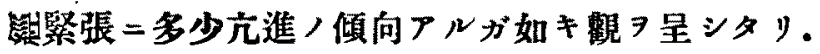

\begin{tabular}{|c|c|c|c|c|c|c|c|}
\hline & $\Gamma \tau ト ゙ \nu+\nu 」$ & 「ピ口カルピン」 & $\Gamma \tau$ & $r$ & म & ど & 21 \\
\hline 1. $45 \mathrm{j}$ 우 & - & + & & & H & & \\
\hline 2. $26 \mathrm{j}$ 令 & + & H & & & + & & \\
\hline 3. $35 \mathrm{j}$ 舍 & + & $\#$ & & & + & & \\
\hline
\end{tabular}

刃慢性鉛毒患者ニテ 1 例二於テハ「アトロピン」注入ニヨリンノ疝痛 タルモ, 他 1 例二於テハ「ビロカルピン」反隼ナク,「アドレナリン」及ビ「アトロ ビン」ニ敏感ニシテ, 即チ副交感融經㗨張減弱二基ク交感神經緊張立進ノ狀 $尹$ 呈シ, 且「アトロビン」泩入 Angiospastische Gefāßkrise =テ說明セラルルモ, スベラコレニテハ說明セラレザルモ ノナランカ.

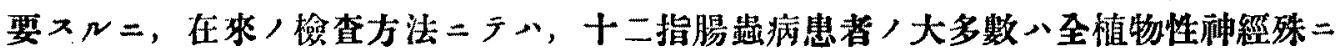

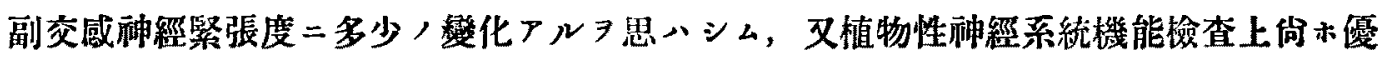
レタル方法ノ案出セラレンコトタ望ムヤ切ナリ。

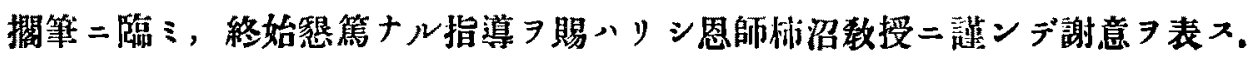

(14，6，24. 原稿受領)

\section{文 (圭ナルも)}

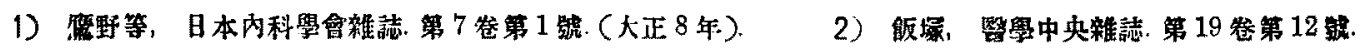

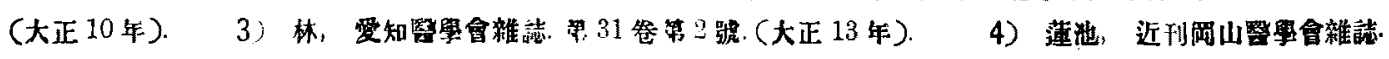

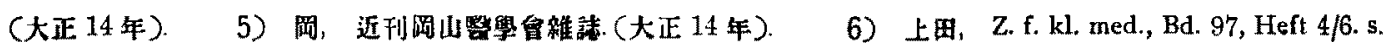

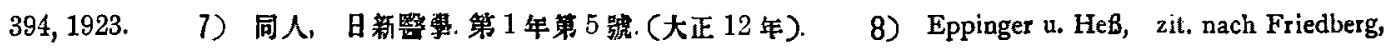

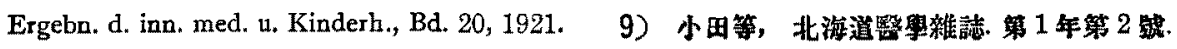


Kurze Inhaltsangabe.

\title{
Pharmakologische Untersuchungen des vegetativen Nervensystems bei Anchylostomiasis und anderen.
}

\author{
Von Dr. Y. Tsunashima. \\ (Aus der medizinischen Universitätsklinik von Prof. Dr. K: Kakimuma, an Okayama.) \\ (Eingegangen am 24. Juni 1925.)
}

Über die Pathogenese der Anämie bei Anchylostomiasis herrscht noch keine bestimmte Anschanung. Neuerdings sind zudem von mehreren Seiten die Entstehung von Anämien im allgemeinen und auch deren Behandlungsweise usw. auf konstitutionelle Momente, besonders z. B. auf die Schilddrüse und ihre Funktionen bezogen. Von diesem Standpunkt aus habe ich pharmakologisch mit Adrenalin, Atropin und Pilocarpin den Zustand des mit den innersekretorischen Organen innig gebundenen vegetativen Nervensystems bei Anchylostomiasis erforscht. Ebenso wurde es auch bei anderen Krankheiten, z. B. bei Diabetes, Parkinsonismus, Bleivergiftung und Morphinismus geprüft.

Unter 11 Anchylostomiasis-Kranken, welche mössige Anāmie und Eosinophilie zeigten, reagierten gegen Adrenalin nur 2 Fälle ziemlich stark, übrige nur ganz geringfügig, sogar zeigte ein Fall keine Reaktion. Gegen Pilocarpin war ein Fall unempfindlich, übrige Fälle reagierten aber mässig stark, ebenso, wenn auch weniger ausgesprochen, doch auch mässig gegen Atropin. Es schien also bei Anchylostomiasis grösstenteils sich um Labilitāt des gesamten vegetativen Nervensystems, spez. um Vaguslabilität, bei welcher es zwar mehr zur Pilocarpinempfindlichkeit neigte, zu handeln, nur ein Fall verhielt sich wie bei Sympathikotonie infolge von Vagushypotonie.

Durch Thyreoidingabe (täglich $0,3 \mathrm{~g}, 3$ Tage lang) ist bei einem Anchylostomiasis und Diabetes und Morphinismus die Atropinreaktion anscheinend mehr ausgeprägt als sonst geworden.

Ob man aber aus Resultaten mit solchen die Endigungen des vegetativen Nervensystems beeinflussenden Mitteln, wie Atropin, Pilocarpin und Adrenalin, über den gesamten Verhalten je im betreffenden Systeme des vegetativen Nervensystems beurteilen und sogar dasselbe in die 2 gegeneinander stehenden Systeme, Para- und Sympathicus, wie Eppinger und Hess zuerst hervorhoben, einteilen mag, das ist eine Frage. Hoffentlich kommen anderweitige neueren Methoden für die Funktionsprüfung des vegetativen $\mathrm{Ne}-$ rvensystems. (Autoreferat.) 